\title{
CHARACTERISTICS OF SURGE-TYPE GLACIERS
}

\section{(Abstract)}

\author{
by
}

G.K.C. Clarke and J. Schmok

(Department of Geophysics and Astronomy, University of British Columbia, Vancouver, BC, Canada)

and C.S.L. Ommanney

(National Hydrology Research Institute, Ottawa, Ontario, Canada)

\begin{abstract}
Glaciers can be separated into two classes according to their flow behaviour: normal (relatively steady, annuallyaveraged, flow rates) and surge-type (pronounced non-annual fluctuations in flow rates). Using glacier inventory data, we compared the population statistics of 1637 normal and surge-type glaciers in the St. Elias
\end{abstract}

\begin{abstract}
Mountains, Yukon Territory, Canada. Within the 38 drainage basins analysed, there is a pronounced spatial variation in the concentration of surge-type glaciers, but no obvious environmental control can be evinced. Analysis of the length distribution function for surge-type glaciers reveals that long glaciers (length exceeding $15 \mathrm{~km}$ ) have a greater tendency to be surge-type than short glaciers.
\end{abstract}

\section{A SURVEY OF THE VANDERFORD AND ADAMS GLACIERS IN EAST ANTARCTICA \\ (Abstract)}

by

E.R. Davis, D.J. Jones, V.I. Morgan and N.W. Young

(Antarctica Division, Department of Science, Kingston, Tasmania 7150, Australia)

\section{ABSTRACT}

A comprehensive, airborne survey of the Vanderford and Adams glaciers was started in January 1983, continued through the austral summer season $1984 / 5$, and completed in February 1985.

Ice-thickness and surface-elevation data were collected over some 4500 square kilometres, on a grid spacing of approximately 5 kilometres.

The measurement system was based on a Bell 206 helicopter, fitted with ANARE $100 \mathrm{MHz}$ ice radar, Motorola Mini-Ranger navigation equipment, and a digital, pressure altimeter. A JMR, satellite, doppler receiver was used to position the navigation ground stations precisely. Gravity measurements were used to fill in ice-thickness coverage, where the ice radar failed to produce an echo and also to help determine where the glacier was floating.

Ice-movement profiles were measured across the front sections of the glaciers and additional spot values were obtained further upstream by utilizing the $3 \mathrm{~m}$ accuracy of the navigation equipment to locate markers quickly at both the beginning and end of the season's work.
A data logger in the helicopter recorded time, navigation distances, aircraft to ground clearance, and air pressure, at 10 second intervals. These data were later merged with manually-scaled, ice-thickness values, for computer processing.

The results show that the Vanderford glacier dominates the system and drains about 5 cubic kilometres of ice per annum, mainly from the inland ice sheet to the south. Ice flowing into the Adams Glacier tends to come from nearer the coast and to the south and west of the glacier. Bedrock topography beneath the Vanderford shows that the deep, inland trench, similar to that found below other outlet glaciers, drops to $2500 \mathrm{~m}$ below sea level, 60 kilometres from the front. The trench has steep sides to the east and gives a clearly-defined edge to the fast glacier flow. The western side, however, is much more complicated, particularly further inland, where the flow is not clearly separate from that of the Adams glacier. 